\title{
1 The twentieth century: dams and the epic struggle to control nature
}

\section{INTRODUCTION}

For eons, rivers began their unimpeded treks to the oceans as trickles of water in the highlands of their watersheds. Making their way down mountain faces, initially via braided streams - and as they aged along flat lands - they descended vigorously and freely into torrents. Six thousand years ago, however, man began a centuries' long quest to tame these watercourses. From that moment in Mesopotamia when the first dam ${ }^{1}$ was constructed on the Euphrates River, ${ }^{2}$ man has worked with vigor to break the natural flow of rivers by channeling, obstructing, barricading, and damming them.

At no time in human history was this phenomenon truer than in the twentieth century. During that 100-year period, man - in the guise of engineer - was engaged in an epic struggle with Mother Nature, in order to vanquish and subjugate her. This Oedipal battle to construct a "wholesale transformation of natural environments,"3 which produced electricity, irrigated heretofore barren lands, and nourished urban expansion, went hand in hand with the fabrication of nature. ${ }^{4}$ Worldwide, only pocket-sized and limited stretches of rivers run wild today. Previously free-flowing rivers across the planet have been domestic-

1 "A dam is a barrier that impounds water and generally serves the primary purpose of retaining water." Wisconsin Department of Natural Resources, Dam Safety (last updated, September 10, 2014), at http://dnr.wi.gov/topic/dams.

2 See generally, Itzchak E. Kornfeld, Trouble in Mesopotamia: Can America Deter a Water War between Iraq, Syria, and Turkey? 34 Envt'l L.R. (2004) 10362; Itzchak E. Kornfeld, Mesopotamia: A History of Water and Law, in Joseph Dellapenna and Joyeeta Gupta (eds.) The Evolution of the Law and Politics of Water (2009) 21-36.

3 Denis Cosgrove, An Elemental Division, in Denis Cosgrove and Geoff Petts (eds.) Water Engineering and Landscape: Water Control and Landscape Transformation in the Modern Period (1990) 8.

4 Maria Kalika, Dams as Symbols of Modernization: The Urbanization of Nature Between Geographical Imagination and Materiality, 96 Ann. of the Assoc. Am. Geographers (2006) 276, 277. 
ated by an estimated 840,000 dams, including some 40,000 large dams whose four-story (15 meters) heights loom out across the landscape. ${ }^{5}$

Indeed, man's modernist propensity to subdue and tame nature has fostered a pursuit for control over her. Numerous scholars have described this penchant as "Modernity's Promethean Project." Prometheus was the acknowledged father of the arts and sciences in ancient Greece. Twenty centuries after his death, during the Age of Enlightenment, both scientists and engineers were accorded Prometheus' mythological status and assumed his mantle of eminence as a "Cultural Icon" and "Modern Hero."7

However, even cultural icons and heroes can disappoint. In fact, in the past several decades, humankind has moved from Edward Teller's “scientific horror," begot by the power of nuclear weapons, to the cataclysm of Katrina caused by the Army Corps of Engineers' shattered promises to protect New Orleans from category 5 hurricanes. "[T] he heroes of modernity promised to dominate nature and deliver human emancipation employing imagination, creativity, ingenuity, a romantic heroic attitude, and a touch of hubris against the given order of the world." 8

These processes have been conceptualized by a number of social science scholars, as part of one single development: "the urbanization of nature." Nevertheless, despite the devastating effects that dam projects have had upon the modern and rural landscape, their effect on the socio-environmental fabric,

5 See e.g., Christine A. Klein, On Dams and Democracy, 78 Or. L. R. (1999) 641, 646; and Patrick McCully, Silenced Rivers, The Ecology and Politics of Large Dams (1966) 3-4 ("estimates of the leading dam industry association, the International Commission on Large Dams, and defining 'large' dams as those fifteen meters or more from foundation to crest").

$6 \quad$ Kalika, note 4, at 277.

7 Ibid. The Age of Modernity began in the seventeenth century and is characterized by a forward-looking, new world view, as well as a contemporary paradigm with new cultural expectations. See generally, Z. Bauman, Modernity and Ambivalence (1991); and S. Toumin, Cosmopolis: The Hidden Agenda of Modernity (1990) for embodiments of the dialectics between opposing views.

8 Kalika, note 2, at 277.

9 Ibid. See also, Gene Desfor and Roger Keil, Nature and the City: Making Environmental Policy in Toronto and Los Angeles (2004); William Cronon, Nature's Metropolis: Chicago and the Great West (1991). Kalika, note 2, at 278, defines this phenomenon as " $[\mathrm{t}]$ he dialectics between the production of nature and the production of cities is paradigmatically manifested in dam projects: transmuting 'natural' landscapes in their making the production and expansion of urban landscapes possible, these technological shrines exemplify the messy dialectics between creation and destruction inherent in Modernity's Promethean Project." 
their impact has received little scrutiny in either the popular, natural resources law, or human rights literature. ${ }^{10}$

Today, dams are the poster child of man's propensity to urbanize or tame nature - or more correctly, mankind's "new" power to control nature. They are viewed as the great concrete cathedrals of the Western neoliberalism. In fact, during his term as President Clinton's Secretary of the Interior, Bruce Babbitt, referring to the United States, noted that "many of these dams have become monuments, expected to last forever."11 Americans and visitors from abroad visit "dams like the Hoover Dam on the Colorado River or the Grand Coulee Dam on the Columbia River"12 like modern pilgrims to a holy shrine, albeit a concrete one. They are awestruck and reverential "at the dramatic evidence before them of the newfound power to control [rivers specifically and] nature [in general]." 13 But at what cost?

This book assesses the cost that dams have exacted on the rights of human beings, as well as the consequence of dams on natural resources, such as wetlands, fish, endangered species, and their loss's impact on humans and their rights. The next chapter, entitled "America and the age of dams," traces the dam construction frenzy that gripped the United States for over 50 years, beginning in the late 1920s. As in so many fields, the rest of the world has followed the United States' lead in constructing dams. Thus, a historical excursion along the Colorado River Basin, where it all began, will lay the groundwork for a good deal of the book. The sheer cost of the "concrete jungle," i.e., dams, in the wilderness has been the destruction, subjugation, and obliteration of the world's free-flowing rivers, beginning with the Colorado River, its delta, and its attendant floral and faunal resources.

\section{WHAT FOLLOWS: THIS BOOK'S ORGANIZATION}

That cost is explored and elaborated upon in the following chapters. Chapter 2 discusses the beginning of the age of mega-dams. Entitled "America and the age of dams," it begins with a review of the late 1920s depression-era construc-

\footnotetext{
10 Kalika, note 2, at 277.

11 Bruce Babbitt, "Dams are not Forever." Ecological Society of America. Remarks of Interior Secretary. Baltimore, Maryland. August 4, 1998 cited in Friends of the Earth, American Rivers, and Trout Unlimited, Dam Removal Success Stories (December 1999), at viii, note 3, at https://www.michigan.gov/documents/dnr/damsuccess_513764 7.pdf.

${ }_{12}$ Robert H. Nelson, Environmental Religion: A Theological Critique, 55 Case W. Reserve L. R. (2004) 51, 58.

13 Ibid.
} 
tion of the Boulder Dam, now known as the Hoover Dam. Chapter 3 addresses human rights law. Chapter 4 discusses the World Bank and its funding of dam building, as well as, the Bank's Inspection Panel.

The subsequent chapters comprise case studies:

- Chapter 5: the Yacyretá Dam, located on the Parana River, between Argentina and Paraguay. Its construction led to the ousting of indigenous people from their homelands and the loss of their ability to employ a special clay for making various artifacts. Yacyretá is also an archetype for corruption and billions of dollars in cost overruns, among other problems.

- Chapter 6: the Manantali and Diama Dams, on the Senegal River, in Senegal. These dams destroyed the ecology of the region and the ability of the indigenous tribes to farm, as well as causing the onset of hunger and malnutrition and a widespread disease caused by parasitic flatworms called schistosomiasis.

- Chapter 7: Turkey's GAP; the Southeast Anatolian, Ilisu, and Birecik Dams. These dams and their reservoirs destroyed tens of thousands of cultural artifacts and the legacies of early civilizations, as well as those of the Kurdish people, who have occupied the region for hundreds of years. Additionally, the seismically active zone along which the dams sit is discussed.

- Chapter 8: The Narmada Dam, India. This dam and others in India triggered the ousting of thousands of tribal peoples, whose ancestors had lived for thousands of years in the region. Moreover, the dam's construction was fought by the tribals all the way to India's Supreme Court.

- Chapter 9: The Kariba Dam, Zambia. The dam was the death blow to the communities and culture of the Gwembe Tonga and Kore Kore peoples. Moreover, many animals were ousted and rescued in "Operation Noah" and the "Creation of Wildlife Sanctuaries."

- Chapter 10: The Xayaburi Dam, on the Lower Mekong, in northern Laos. The key issues include treaty violations and failure to analyze the dam's transboundary impacts prior to construction and the loss of one of the world's richest freshwater fisheries.

- Chapter 11: The Oldman Dam, along the Oldman River, in southwest Alberta, Canada. Here, First Nations indigenous peoples sued for an environmental impact study to determine whether the dam should be built. Rather than assess that critical issue, the Supreme Court of Canada converted the request to a legal, constitutional issue, between the provincial and federal governments. 